\title{
INTERNATIONAL LAW AS LEGAL SYSTEM: LEGALITY, LEGITIMACY, AND LEGAL POSITION OF STATES
}

\author{
Roman Kwiecień*
}

The preliminary thesis of this paper is as follows: the relationship between legality and legitimacy in the field of international law, as in any legal order, can be seen with superior clarity in the perspective of law conceived of as a system. Indeed, this approach to law is a systemising and synthesising value, and, consequently, makes it easy to capture the interaction between legality and legitimacy. This is not only important but also controversial, something that the phrase "illegal but legitimate," popularised over the last two decades, encapsulates perfectly.

This paper consists of four main parts. The first concerns 'systemicity' as a research approach to law. The second seeks to explain the concept of a legal system, outline the systemic features of international law, and present the main research issues related to international law as a legal system. The significance of a legal position of States for these problems is emphasised. The third part attempts to demonstrate the importance of connections between legality and legitimacy in international legal problems, while the fourth deals with the relationship between legality and legitimacy under systemic features of international law. Final remarks conclude the study.

* Professor of International Law, Maria Curie-Skłodowska University. This article was prepared as a part of Polish National Science research grant No. DEC-2011/03/B/ HS5/01369. 


\section{1. 'Systemicity' as a research approach to international law}

The term 'system' is ascribed some evaluative meaning because the concept it designates is associated with the ordering of mutual relations between its elements. With regard to law, it is expressed by the fact that a system is but a developmental stage of a mature legal order; therefore, not every legal order is a system. However, the systemic approach ('systemicity' as a research approach), due to its significant cognitive advantages, can be applied to research on any legal system.

The term 'system' is more commonly applied to domestic law than to international law. There are several reasons for the above. A 'system' is intuitively associated with a compact and coherent whole, structured according to set criteria. Meanwhile, the traditional voluntarist view of international law presents it as an archaic and horizontal legal order, based on rules and principles approved by States and, due to its relatively restrictive character, incapable of ensuring a sustainable and coherent order within general international legal regulations. New doctrinal approaches, aiming to present the law of the international community as a global law, combine, within the framework of global governance, the mechanisms of national law with the intergovernmental factor and the role of non-State actors, and yet remain unable to convincingly justify such systemic pillars, blurring the nature of law in international relations. In other words, the normativity of public law is difficult to justify within their framework. Another argument for the asystemic approach to international law involves a striking lack of interest in international law expressed in the works of legal theorists. In the $20^{\text {th }}$ century, it was systematically studied only by a limited number of scholars. Those worth mentioning include Hans Kelsen, Alfred Verdross, Hersch Lauterpacht, Alph Ross, Carl Schmitt, and Herbert Hart. Does this lack of wider interest, which is only partially explained by the 'otherness' (a different structure and dogmatic core) of international law as compared to national law with the resulting fear of entering terra incognita, combined with the prevailing scepticism as to its juridical nature, mean denying international law the features of a system, or is it of little relevance? From the perspective of States, international organisations, and other actors in international relations, the significance of this problem is negligible, as it goes beyond their specific, practical tasks, objectives, and functions. From the point of view of the science of law and official bodies involved in the codification and development of international law, this matter looks quite different. It is symptomatic that the Study Group of the International Law 
Commission (ILC) on the Fragmentation of International Law opens its conclusions with the following statement:

International law is a legal system. Its rules and principles (i.e. its norms) act in relation to and should be interpreted against the background of other rules and principles. As a legal system, international law is not a random collection of such norms. There are meaningful relationships between them. ${ }^{2}$

The approach adopted by the Study Group is valuable for cognitive reasons, regardless of whether we deem them a statement of the status quo or merely a de lege ferenda remark. The purpose of science is to explain and conceptually organise reality. A systemic approach seems advisable, or even necessary, in that respect. Can one consistently speak of any legal order without directives or guidelines to systemise the order? The issue was aptly addressed by Joseph L. Kunz, who, with reference to the science of international law, wrote the following:

The first and principal task of the science of international law is to present the international law actually in force, to present it in its totality and in a systemic way. For a science is, in the words of Kant, not a mere aggregate, but a system; and in order to arrive at a system, we need a method, i.e. a procedure according to principles of reason by which alone a diversity of cognitions can become a system. The science of international law has always been faced with the systematic problem. ${ }^{3}$

Indeed, the part of the science of law that rejected the minimalist approach to international law as a collection of random - or, in fact, contradictory-legal rules, was always aware of the problem of the systemicity of its subject matter. Thus, it has been aware of the fact that a full explanation of specific powers and legal obligations existing in particular circumstances is impossible outside of the normative context of their operation, i.e. the perspective of a certain compact whole. In other words, the non-minimalist science of law always sought an appropriate methodological and ontological

2 Conclusions of the Work of the Study Group on the Fragmentation of International Law: Difficulties Arising from the Diversification and Expansion of International Law, UN Doc. A/ Res/61/34, at para. 1(1).

3 J.L. Kunz, The systematic problem of the science of international law, [in:] idem, The Changing Law of Nations. Essays on International Law, Ohio State University Press 1968, at p. 134. 
approach, which was to present international law as a structured set of rules, principles, and legal institutions, and attempted to identify the agent responsible for its systemic characteristics. Finding and convincingly justifying such an approach holds the answer to the question whether international law is a normative chaos or a system. ${ }^{4}$

When we discuss systems, including the legal system, we face a fundamental epistemological and ontological problem concerning the definition of a system: whether it is a projection of human cognitive powers, as the epistemological idealism believes it to be, or a reality, existing objectively outside the cognitive subject, as philosophical realism would have it. If it is the former, the systemic concept of law is an intellectual straitjacket put on the legal reality; on the other hand, if the latter is correct, the sole purpose of science is to passively reflect reality. Essentially, the first position seems to be of relevance because the principles and rules of law themselves are, contrary to the laws of physics, chemistry, or biology, asystemic. In other words, there are no logical relations or interdependencies between them, without interpretation. In this sense, the systemising legal thinking shapes legal reality. ${ }^{5}$ The interrelations of the principles and rules of law, which are a prerequisite of systemicity, appear only in relations between interpretation and application, i.e. from the perspective of the actors involved in these processes. Therefore, in its report on fragmentation, ILC emphasised the mutual inter-reference of the norms of international law as an important feature of systemicity, and pointed out the particular importance of Article 31 of the Vienna Convention on the Law of Treaties of 1969 for the 'systemic integration' of international law. ${ }^{6}$ Such an approach

4 Cf. J. Combacau, Le droit international: bric-à-brac ou système?, 'Archives de Philosophie du Droit' 1986, vol. 31, at pp. 85, 95-101.

5 Cf. K. Opałek, Problemy metodologiczne nauki prawa [Methodological problems of legal science], Warszawa 1963, p. 163; N. MacCormick, Institutions of Law: An Essay in Legal Theory, OUP, Oxford 2007, p. 6. The role of international law scholarship for systemic approach to the law of international society was recently highlighted in J. d'Aspremont, Formalism and the Sources of International Law. A Theory of the Ascertainment of Legal Rules, OUP, Oxford 2011, pp. 210-211. He draws attention to the fact that the systematisation of international law was invariably effected through juridical thinking rather than legal practice.

${ }^{6}$ Conclusions of the Work of the Study Group on the Fragmentation of International Law: Difficulties Arising from the Diversification and Expansion of International Law, UN Doc. A/Res/61/34, at para. 4(17). On the significance of Article 31(3)(c) of the VCLT see C. McLachlan, The principle of systemic integration and article 31(3)(c) of the Vienna Convention, 'ICLQ' 2005, vol. 54, at pp. 279-320; A. Kozłowski, Interpretacja systemowa 
indicates the key importance of interpretation in systemic thinking. Today, its significance is particularly emphasised in certain hermeneutic and functionalistically-oriented trends in jurisprudence. ${ }^{7}$ Nevertheless, we should remember that it was recently argued by Hans Kelsen - unsurprisingly, given the Kantian intellectual roots of his thought - that a legal system is a product of lawyers who systemise, or order, legal regulations in the process of interpretation. It is interpretation, namely, the cognitive relation between the subject performing the act and a specific provision, that is largely responsible for the presence or absence of systemic characteristics, completeness and consistency in particular. Here emerges the importance of the problem of legitimacy, which, by 'filling' gaps in law, can contribute to its completeness and thus systemicity. The presented point of view is not tantamount to extending unconditional support to the concept of law as an 'interpretative fact.' This is merely to emphasise that only the process of interpretation of a particular provision in a specific context allows us to identify its position in relation to other regulations, which, in turn, enables us to treat collections of regulations as a certain structured whole or, in other words, as a system. Naturally, the effect of the interpretative process may not be preordained in advance, as it depends both on the knowledge and interpretative skills of the interpreter. While applying the category of a system is certainly not necessary for legal actors, ${ }^{8}$ it turns out to be

prawa międzynarodowego [Systemic interpretation of international law], [in:] J. Kolasa, A. Kozłowski (eds.), Rozwój prawa międzynarodowego - jedność czy fragmentacja? [The development of international law - unity or fragmentation?], UW, Wrocław 2007, at pp. 171, 190-198; A. Kozłowski, Interpretacja traktatu międzynarodowego w świetle jego kontekstu [Interpretation of an international treaty in its context], Wydawnictwo Sejmowe, Warszawa 2002, passim; J. d'Aspremont, The systemic integration of international law by domestic courts: domestic judges as architects of the consistency of the international legal order, available at http://ssrn.com/abstract=1401019; J.-M. Sorel, V. Boré Eveno, Art. 31, 1969 Vienna Convention, [in:] O. Corten, P. Klein (eds.), The Vienna Conventions on the Law of Treaties, OUP, Oxford 2011, at p. 829; G.O. Zabalza, The Principle of Systemic Integration: Towards a Coherent International Legal Order, LIT Verlag, Zürich-Berlin 2012, at pp. 235-307.

7 See I. Venzke, How Interpretation Makes International Law. On Semantic Change and Normative Twists, OUP, Oxford 2012, pp. 29-37.

8 Joseph Raz put it as follows: “The term 'a legal system' is not a technical legal term.... Nor is the concept important to the day-to-day administration of law, as are the concepts of contract, ownership, right, duty, and the like. The term is primarily used in thinking about the law, not in the actual use and application of the law.... Therefore, when trying to clarify the notion of a legal system, the legal theorist does not aim at defining clearly the sense in which the term is employed by legislators, judges, or lawyers. He is, 
indispensable for those who seek to identify and explain the constitutive characteristics of a legal order, i.e. for science and, to an extent, courts. It is for the legal science in particular that, regardless of the actual status of the system, thinking in terms of systems is necessary, since science attempts to explain the world by means of specific theories. Every theory, in turn, aims at a holistic explanation of a given aspect of reality, as it would not be a theory otherwise. A theory is not primarily concerned about the practical application of its assumptions. Thus, State bodies, abiding by, or infringing, international law or courts deciding cases on the basis of legal regulations, do not create science but rather are engaged in practical activities involving either making or applying such regulations. Meanwhile, the legal theory, as proclaimed by Kant, is the essence of the established principles, leaving out factors affecting their application. In this sense, it does not depend on the experience, but rather is based on some rational rules upon which human cognitive abilities are founded. Each so-called empirical theory of law is doomed to be arbitrary, as it only allows for the description of law as an accidental set of norms, institutions, and facts that are created in the course of the acts and omissions of the subjects of law. Only non-empirical rational rules allow for organising reality. Kant speaks of the empirical theories of law, or theories of law based entirely on experience, in the following words: "Like the wooden head in Phaedrus's fable, a merely empirical doctrine of right is a head that may be beautiful but unfortunately it has no brain."

Every science is thus somehow doomed to the systemic thinking of its subject matter. Systemic thinking allows a synthesis, which most fully expresses the cognition of a certain part of reality. The science of international law should not be isolated in this respect. It was convincingly argued by Joseph L. Kunz in the passage cited above, and it is also discussed by its other well-known proponents, who see the systemic characteristics of international law as its specific features. ${ }^{10}$ It is not important, at this point,

rather, attempting to forge a useful conceptual tool, one which will help him to a better understanding of the nature of law." J. Raz, The identity of legal systems, [in:] idem., The Authority of Law, $2^{\text {nd }}$ ed. OUP, Oxford 2009, at pp. 78-79.

9 I. Kant, The Metaphysics of Morals, transl. and ed. M. Gregor, CUP, Cambridge 2000, para. 6:230, p. 23.

10 See e.g. L. Ehrlich, Prawo międzynarodowe [International law], 4 ed., PWN, Warszawa 1958, pp. 86; R. Higgins, Problems and Process: International Law and How We Use It, Clarendon Press, Oxford 1994, p. 3; J. Combacau, S. Sur, Droit international public, 4e ed., Montchrestien, Paris 2001, pp. 17-28; J. Crawford, International law as an open system, 
that such characteristics are subject to different interpretations. What is important is the research approach, referred to as 'systemicity.' Let us also remark that it is not a coincidence that the increased autonomy of the science of international law, i.e. its emergence as an individual research discipline, occurred only in the aftermath of the first attempt to present 'the law of war and peace' as a system, at Grotius' time. ${ }^{11}$

Allowing for the need and relevance of the systemic approach to international law, we need to (i) explain the mostly intuitive term 'system,' (ii) indicate the main types of systems, and (iii) preliminarily and hypothetically define the determinants of the systemic characteristics of international law.

[in:] idem, International Law as an Open System, Cameron May, London 2002, at p. $17 \mathrm{ff}$.; Idem, The Creation of States in International Law, $2^{\text {nd }}$ ed., OUP, Oxford 2006, pp. 5-6; Idem, Chance, Order, Change: The Course of International Law, Hague Academy of International Law 2014, pp. 179-211; M. Shaw, International Law, $6^{\text {th }}$ ed., CUP, Cambridge 2008, pp. 5-11; A.L. Paulus, International legal system as a constitution, [in:] J.L Dunoff, J.P. Trachtman (eds.), Ruling the World? Constitutionalism, International Law, and Global Governance, CUP, Cambridge 2009, at pp. 74-76, 107; P.F. Diehl, Ch. Ku, The Dynamics of International Law, CUP, Cambridge 2010, pp. 2-7. The conviction on systemic features of international law is shared by the chairman of the Study Group of the International Law Commission on the Fragmentation of International Law - Martti Koskenniemi, who notes: "Far from being merely an 'academic' aspect of the legal craft, systemic thinking penetrates all legal reasoning, including the practice of law-application by judges and administrators." M. Koskenniemi, Study on the function and scope of the lex specialis rule and the question of self-contained regimes, ILC(LVI)/SG/FIL/CRD.1 and Add 1, para. 29. Cf. M. Koskenniemi, The fate of public international law: between technique and politics, 'Modern Law Review' 2007, vol. 70, no 1, at pp. 1, 16-19. It is worth noting that systemic approach to international law has been strongly grounded in German international law scholarship since the $19^{\text {th }}$ century. Today, it is particularly visible in its support for the 'constitutionalisation of international law.' See E. Benvenisti, The conception of international law as a legal system, 'German Yearbook of International Law' 2007, vol. 50, p. $393 \mathrm{ff}$.

11 P.F. Diehl, Ch. Ku, The Dynamics of International Law..., op. cit., p. 10. The authors point at Grotius as the first scholar who understood international law as a unified whole. Thus, Grotius underpinned conceiving international law as a legal system. 


\section{Legal system as a problem of the science of law}

\subsection{The concept of a legal system}

In dictionaries, one can find different meanings of the term 'system.' For instance, The Oxford Dictionary offers the following definitions: 1 . 'set of connected things that form a whole or work together;' 2. 'set of rules or practices used together;' 3 . 'method of classification or notation or measurement;' 4. 'orderliness. ${ }^{12}$ These define a system from different perspectives: ontological, epistemological, methodological, and functional. However, what they all have in common is that they indicate the ordering and organisation according to a certain criterion as the main feature of a system. A system is, therefore, the opposite of an accidental collection of elements. A system, in other words, orders a specific aspect of reality and thus enables its fuller understanding.

Systemic thinking about the world is not a new intellectual paradigm. Already in antiquity, reality was studied through the prism of holism, purpose, and order, which is reflected, for instance, in the philosophy of Aristotle. The $20^{\text {th }}$ century brought the science of systems as a meta-science, which was supposed to organise the knowledge of systems and classify them. A significant contribution to research on the meaning of a 'system' was made through the introduction of the 'general theory of systems,' by the German biologist Ludwig von Bertalanffy, which constituted the theoretical basis of the applied sciences, i.e. sciences aiming to solve practical problems. According to von Bertalanffy, there are models, rules, and regulations that apply to generalised systems or their subclasses, irrespective of their kind or the nature of their constituent elements and the relations or forces between them; therefore, it appears justified to demand a theory and universal rules relating to systems in general, rather than to systems of any specific kind. This gave rise to the aforementioned 'general theory of systems,' whose objective it is to formulate and derive regulations that are important to 'systems in general.' The existence of general system properties accounts for structural similarities (isomorphisms) in different areas, resulting from similarities between the rules 
governing various, inherently different entities. ${ }^{13}$ In the theory of systems, the most important issues are those that were programmatically excluded from the mechanistic sciences, i.e. issues of order, organisation, holism, and purpose. ${ }^{14}$ Von Bertalanffy divided systems into (i) real, i.e. entities seen or deduced, existing independently of the observer (such as a galaxy, an atom, or a dog) and (ii) conceptual, i.e. symbolic constructs, a subclass of which are scientific systems. ${ }^{15}$ Accounting for the emphasised above importance of interpretation for the systematisation of law, it needs to be concluded that law as a system is on the borderline of this classification.

The concept of a legal system serves to indicate a certain ideal pattern for legal relations existing in reality, as it implies their full ordering, consistency, and completeness. A legal system is thus a certain idealistic model, while the systemic view of law is one of the research approaches to the phenomenon of law. The legal system is thus primarily a concept of legal language (legal scholarship and judicial decisions), rather than of legal regulations. At the same time, we should bear in mind the absence of a commonly accepted semantic framework for this concept, which is often used intuitively and treated as synonymous with the notion of a legal order. However, not every legal order must meet the requirements of systemicity. This assertion is not synonymous with the thesis that only one type of legal system is in existence. On the contrary, we can speak of various system types of law. A system type is a form of generalisation of the properties exhibited by a certain group of legal systems. Primarily, one can distinguish the system type of domestic law (and the system of continental law and common law within its framework) and international law.

Within these two main types of legal systems, there are system types distinguished on the basis of the diachronic criterion (the criterion of temporary implications, indicating the evolution of legal orders, such as archaic, ancient, feudal, modern, or contemporary law) or on the basis of the synchronic criterion (taking into account a particular moment in time and presenting a static view with the aim to diversify the legal orders

13 L. von Bertalanffy, Ogólna teoria systemów. Podstawy, rozwój, zastosowania [The General Systems Theory. Foundations, Development, and Usage], transl. E. WoydyłłoWoźniak, PWN, Warszawa 1984, pp. 62-63.

14 Ibid., p. 42.

15 Ibid., pp. 25-26. 
existing at a given moment, e.g. continental law, common law, European law, Islamic law, and Far East law). ${ }^{16}$

Based on these two criteria, one can also examine international law. It is clearly justified to look at international law in light of the diachronic criterion (ancient, medieval, modern ius gentium, international law under the Charter of the United Nations). However, it is perhaps more important to see it in the perspective of the synchronic criterion. Here arises the significant question of what the system of international law is today. Is it the law of States, the law of humanity, or transnational law?

The concept of a legal system serves a twofold function: descriptive and evaluative (prescriptive). In the evaluative (prescriptive) sense, a system of law is of an attributive nature, i.e. it is recognised as a desirable feature of a legal order, allowing us to attribute to it the consistency of its elements, a necessary degree of order and completeness. Such an order is considered to be superior to a legal order, which cannot be attributed to the characteristics of a system. In the descriptive sense, each order can be described as a system, as each has its own specific characteristics.

In this sense, the concept of a legal system serves not only to describe but also to classify legal orders. Accounting for the descriptive function of the concept of a legal system, a system of law can preliminarily be defined as a set of ordered and interrelated (by means of validation rules, conflictof-law rules and exegesis) general and abstract norms from which other legal norms, decisions on the application of law, and principles of law arise, i.e. norms of general application within a legal order that are in force at a specific time and place. A legal system also includes legal institutions and juridical acts carried out by its entities. A central link of legal order understood as such, is the system of legal sources.

After analysing the findings of Herbert Hart, in particular, it is advisable to distinguish between 'primary' and 'secondary' rules within a legal system. The latter indicate the conditions of validity, interpretation, and amendment of primary norms, which, generally speaking, establish the rights and obligations of legal entities. The secondary rules shape the validative and interpretative autonomy of a legal system. Hart distinguishes two minimal conditions necessary and sufficient for a legal system to exist. On the one hand, the rules of behaviour that are in force in accordance

16 A. Bator, System prawny - typ [Legal system - type], [in:] A. Bator et al., Wprowadzenie do nauk prawnych. Leksykon tematyczny [Introduction to legal science: thematic lexicon], LexisNexis, Warszawa 2006, at pp. 167-168. 
with the ultimate systemic criteria must be generally respected and, on the other hand, the rules of recognition of a system that define the criteria for the validity of legal regulations - the rule of change and the rule of adjudication - must be effectively accepted as common public patterns of official conduct of different actors. ${ }^{17}$ According to Hart, a condition sufficient for a legal system to exist is the unity of the primary and secondary rules. At the same time, it is worth bearing in mind that Hart himself questioned the systemic nature of international law, due to the absence of secondary rules in it, and considered this law as an archaic legal order. ${ }^{18}$ Is this thesis of the early 1960s still valid today? It is impossible to provide a comprehensive answer to this question without taking into account the legal position of States.

Thus, in the first place, the status of States influences whether international law is a legal system, and secondly, it influences its specific features as a system. In particular, the legal position of States (in particular the consent of States as, potentially, the main source of normativity in the law of the international community) determines whether international law can be regarded as a complete system, i.e. a system that clearly defines the criteria for the recognition of norms, institutions, and acts, as its components. Secondly, the position of States is also, as it seems, of essential significance for such an important feature of a legal system as its ordering. It is, therefore, responsible for answering the question whether international law is consistent, or at least not contradictory, and whether, and in what sense, one can speak of a hierarchy of sources and obligations within it. This status of States as 'international legislators' and major entities administrating 'international justice' is also of paramount importance for the relations between legitimacy and legality.

Traditional, primarily positivistic, theory of law usually emphasises relations between norms, rules, and principles (or normative acts or provisions) and institutional intra-system interactions, rather than external influences, which is a key element of, for instance, Niklas Luhmann's theory of system. In this traditional approach, attention is drawn to the ordering of elements as a prerequisite for systemicity. The positivistic approach is based on the cognitive and ontological realism, i.e. the argument that

17 H.L.A. Hart, The Concept of Law, $3^{\text {rd }}$ ed., OUP, Oxford 2012, p. $100 \mathrm{ff}$.

18 Ibid., pp. 213, 214-216. Compare: J.L. Hargrove, International law as law, law as a system of rule-governed conduct, 'Villanova Law Review' 2011, vol. 56, at pp. 509-521, where Hart's 'secondary rules' are used to justify the systemicity of international law. 
there is an orderly collection of legal elements that form a system. Is it not, however, an idealistic assumption? Is it not that the ordering elements are only a product of bodies administering (courts) and analysing (science) law? The description itself can be justified, as it only offers a statement of facts of various kind which could be (are) ordered only by applying conflict-of-law rules, validative rules, and exegesis. In any case, the concept of a legal system in the positivistic approach is based on the assumption of non-contradictoriness (or consistency), completeness, hierarchicality and - although ambiguously discussed in the relevant literature - openness/completeness. ${ }^{19}$ There is no need at this point to definitively decide whether this approach is sufficient for a systemic analysis of law; however, it is advisable to stress its necessity for such an approach.

An essential cognitive problem still under dispute is the source of the normativity of a legal system, as it determines the formal unity of a system. ${ }^{20}$ This issue is also crucial for the legitimacy of law and in law, as the source of normativity of law is what legitimates law. Positivists and normativists see it in a legal system itself, in which they look for the so-called criteria of belonging (to a system). The defining characteristics here are the concepts of Austin, who saw the source of the normativity of law in its being established by the sovereign, or Kelsen - seeing it in the hypothetical Grundnorm, or Hart - indicating the fundamental role of the 'secondary' rules in this respect. Such solutions raise objections in non-positivist jurisprudence, which primarily questions the capacity of legal rules making up a legal system to justify per se its normative validity. John Finnis straight-forwardly argues:

[T]he proposal to base the unity of the legal system on a rule from which perhaps no other rules in the system are derived, and which is often [...] of the most ambiguous and disputable character [...] - this proposal is so bizarre that one may suspect that its origins are ideological rather than purely theoretical. [...] The legal system, considered simply as a set of 'valid rules,' does not exist, since, considered simply as a set of rules, of inter-dependent normative meanings, there is nothing prawoznawstwa [Basic problems of jurisprudence], PWN, Warszawa 1980, pp. 218-243; Z. Ziembiński, S. Wronkowska, A. Redelbach, Zarys teorii państwa i prawa [The outline of the theory of state and law], PWN, Warszawa 1994, pp. 218-227; R. Sarkowicz, J. Stelmach, Teoria prawa [Legal theory], UJ, Kraków 1996, pp. 154-170.

${ }^{20}$ Cf. J. Raz, The identity of legal systems, op. cit., at p. 79. Raz points out that the identity of a legal system follows from its formal cohesion. 
to give it continuity, duration, identity through time. As Eric Voegelin has pointed out, the existence in continuity of a legal system can no more be explained by reference simply to sequences of sets of valid rules than can motion, as Zeno discovered, be explained by reference to sequences of points. ${ }^{21}$

Indicating the source of normativity of a legal system is, indeed, a key issue in the theory of law, as it concerns the justification of the normative identity of a legal order. What should, however, be kept in mind in this respect is Joseph Raz's warning of too hasty a generalisation and uncritical translation of the solutions of one system of domestic law to another system. ${ }^{22}$ This warning gains particular importance with regard to international law, which, if only from the point of view of its entities, sources, or mechanisms of legal enforcement, is distinct from national law. This is largely due to the specific position which States hold in international law. Without an analysis of the legal position of the State and its consequences for international law, it is difficult to characterise the international legal order in the context of its systemicity or asystemicity. Our main problem can be formulated as follows: (i) does the status of States justify the systemic nature of international law; (ii) to what extent is it responsible for its characteristics, (iii) and to what extent does it influence the question of the source of the normativity of international law?

The large quantity of publications on the status of States in international law may suggest a satisfactory state of knowledge in this area; this, however, is only true at first glance. In fact, the science of law remains divided in terms of the importance and role of the legal position of States with respect to international law. It is about the division between the supporters of the longstanding tradition of seeing States as the main and most important entity of international law - 'international legislators,' and the supporters of the ever-growing trend questioning the key role of the subjectivity of States in international law. According to the former, international law is primarily an inter-state law, whereas for the latter, it is a common law of humanity, focusing on individuals and other non-State actors, and thus relativising, or even marginalising, the position of States. Another important argument against the satisfactory state of knowledge on the relation between the State and the system of international law

21 J. Finnis, Revolutions and continuity of law, [in:] Idem, Philosophy of Law. Collected Essays: Volume IV, OUP, Oxford 2011, p. 428.

22 J. Raz, The identity of legal systems, op. cit., at pp. 82-85. 
is the still incomplete explanation of the consequences of the status of States for the systemic characteristics of international law. Contrary to appearances, this problem is rarely discussed, ${ }^{23}$ and any views professed in this regard are based on intuition rather than on discursive research. With the exception of works by Kelsen and Lauterpacht, such research is yet to be conducted, particularly with respect to the aforementioned trends. The reason for this is not so much an absence of attempts as their unsatisfactory results, determined by research hypotheses that lack objectivity. For example, the researchers emphasising the central position of States in international law often base the binding force of this law on the consent of States; consequently, they sometimes arbitrarily speak in favour of the non liquet doctrine. The supporters of this position reject the consent of States as the factor legitimising international law and present it as a closed and complete legal system, whose the source of normativity lies beyond the rules and principles of so-called positive laws that make up the system. It is advisable to view these commonplace schemes, or even research paradigms, critically. This can make a certain contribution to the theory of international law, due to the verification of the bi-polar scheme of the international-law status of States, which is present in the science of law.

\subsection{Review of main research issues concerning international law as a system}

In light of the above-mentioned works of the Study Group of ILC on the Fragmentation of International Law, international law is a contemporary legal system. Even if this conclusion is true, it poses the question of what system this law belongs to. Is it a closed system, in the sense that it comprises basic standards that constitute the main criteria of reference for other norms, or, on the contrary, is it an open system, which allows for the introduction of external norms? Another contentious issue, which has already been mentioned, can be formulated as follows: is international

${ }^{23}$ See e.g. J. Combacau, Le droit international: bric-à-brac ou système?, op. cit., at pp. 95-101, A. Kozłowski, Interpretacja systemowa prawa międzynarodowego [Systemic interpretation of international law], op. cit., at p. 179 and A. Carty, The Decay of International Law? A Reappraisal of the Limits of Legal Imagination in International Affairs, Manchester University Press, Manchester 1986, pp. 1, 8-10. Carty argues that the international legal status of States does not allow for the treatment of international law as a legal system. 
law a complete system, i.e. a system protected against thetic (constructive), axiological, and logical gaps? Consequently, can a legal order that aspires to become a system allow for non liquet situations at all? Another fundamental question is whether international law is characterised by sufficient consistency, manifesting itself in the absence of contradictions, and the presence of specific content and competence ties between norms. Do we, consequently, encounter a specific hierarchical and axiological order, based on basic rules characterised by normative unity, when dealing with international law? Let it be restated that without accounting for the legal position of States following from their sovereignty, it is not possible to provide an answer to such questions.

The consequences of sovereignty for the problem of the systemic nature of international law are particularly significant in the form of the socalled Lotus doctrine, formulated by the Permanent Court of International Justice (PCIJ), which remains important in the jurisprudence of the International Court of Justice (ICJ). Its essence boils down to the thesis that any restriction of the freedom of States' actions must have a clear legal basis and cannot be presumed. Thus, the legal obligations of States arise from their consent. The Lotus doctrine and its consequences for the issues of the systemic nature of international law are of fundamental significance because they present States as 'international legislators' whose actions determine the completeness of this law as a system. Additionally, it has enormous implications for the problem of legality and legitimacy, as the resulting interpretive directives in the form of the prohibition of presumption in placing restrictions on States' freedom of actions, have an impact on what is legal and illegal. In view of the above, it is not unreasonable to ask whether the ontology of a State as a sovereign being enables the ontology of international law as a system.

The problem of the systemicity of international law also requires a reference to the phenomenon of the fragmentation of international law, related to the objective and subjective expansion of its regulation. ${ }^{24}$ This fragmentation may raise doubts concerning the full control of States over the legislative process in the international community. The norm-setting function, held today by a number of non-State actors, makes some authors put forward the thesis that the international community is reaching the

24 Cf. A.L. Paulus, International legal system... op. cit., at pp. 82-87. 
post-State stage of its development. ${ }^{25}$ Moreover, the autonomisation of some regulatory regimes is considered a threat to the normative unity of international law (which was the premise of the previously mentioned works of the Study Group of ILC on the fragmentation phenomenon). This issue goes beyond international law, with theoreticians noticing it also in relation to national law. However, if this claim is true with regard to international law (i.e. the international legal order is merely a conglomeration of different autonomous orders), then the question arises whether speaking of the system of international law is not groundless, since it negates the constitutive features of the international legal order. In other words, it calls into doubt the normative unity, consistency, completeness, and universality of the system. In this perspective, international law would be characterised by the pluralism of autonomous legal orders, lacking a cohesive systemic 'spine.' This asystemic, or even an anti-systemic, approach is certainly in opposition to the approach which depicts international law as a uniform, universal, complete, and even more constitutional legal order.

\section{Legality, legitimacy, and international law}

It is appropriate at this point to explain the systemic features of law: completeness and consistency (non-contradictoriness), which are linked to the ordering of relations between legal rules, as well as unity and openness/ closeness.

Completeness has several dimensions: validative, qualificative, and decisional. ${ }^{26}$ One can speak of validative completeness of a system when every single element of the system can definitely be said either to be part of the system or not. In this sense, a complete legal system is a system that is characterised by clear criteria of specific elements (principles, rules, in-

25 See N. Krisch, Beyond Constitutionalism. The Pluralist Structure of International Society, OUP, Oxford 2011; J. d'Aspremont (ed.), Participants in the International Legal System. Multiple Perspectives on Non-State Actors in International Law, Routledge, LondonNew York 2011 and, critically, R. Kwiecień, On some contemporary challenges to statehood in the international legal order: international law between 'Lotus' and 'global administrative law, 'Archiv des Völkerrechts' 2013, vol. 51, no 3, at p. 279 ff.

${ }^{26}$ Cf. e.g. A. Bator, Zupełność systemu prawa [Completeness of legal system], [in:] A. Bator et al., Wprowadzenie do nauk prawnych. Leksykon [Introduction to legal sciences. A lexicon], op. cit., at pp. 169-170. 
stitutions, etc.) comprising it. The issue of validative completeness remains closely related to the question of openness/closeness of a legal system.

Qualificative completeness of a system allows us to define every action within it either as an action that is legally relevant and causes specific legal effects (order, injunction, right) or as an action that is legally irrelevant, i.e. an action that does not produce legal consequences.

Decisional completeness of a system is achieved when in any dispute the competent bodies are capable of providing legal grounds for its resolution. In this sense, a complete system is thus devoid of loopholes. ${ }^{27}$ Therefore, decisional completeness excludes non liquet situations. This obviously desirable state of affairs is conditioned by the qualificative completeness of the system.

The systemicity of international law remains closely related to its universality and unity. The normative unity of international law argues in favour of its systemic character, as it emphasises its consistency, or at least the internal capacity for resolving conflicts of norms and jurisdictions, whereas universality contributes to its completeness. The system of international law, as already mentioned, remains constricted by the general rules of law, which, due to their nature, are the formal source of universal international law, i.e. the rules of the universal scope within the legal space which with regard to the international community is primarily determined by legal relations between its sovereign members and entities that are subject to its jurisdiction.

Joseph Raz speaks about the unity of a legal system in a material and formal sense. ${ }^{28}$ The material unity of a legal system, as Raz argues, constitutes its distinctive characteristics, which depend on the content of regulations and their ways of application. It will hereinafter be referred to as normative unity. The formal unity of a legal system manifests itself in the identity of a legal system, which is constituted by a criterion or a set of criteria defining the conditions or norms comprising the system. In light of remarks made in this paper, an elemental question arises as to the role of the States' consent as a factor that determines standards (principles and rules) belonging to international law, or, in other words, the question whether the legal position of States, their role as 'international legislators,'

27 See R. Sarkowicz, J. Stelmach, Teoria prawa [Legal theory], op. cit., pp. 168-170; Z. Ziembiński, Podstawowe problemy prawoznawstwa [Basic problems of jurisprudence], op. cit., pp. 218-225.

${ }^{28}$ J. Raz, The identity of legal systems, op. cit., at p. 79. 
ensures the formal unity of international law. If States are indeed 'international legislators' then their position largely determines the sources of the normativity of international law.

Without arriving at a contradiction, it is impossible to argue in favour of the systemicity of international law without simultaneously recognising its normative unity and universality. Normative unity assumes the presence of rules sorting out relations between norms and thus allows for the consistency among them, which is one of the conditions of systemicity. Let us note that in this perspective the issue of systemicity will also be associated with contemporary threats to normative unity and universality. They result from a variety of sources: hegemonial aspirations of some States, the growth of standard-setting role of non-State actors, the fragmentation of the legal regimes in the international community, or the diversity of the international judiciary. Therefore, some authors argue that contemporary international law has lost its formal unity to the autonomous legal regimes constituting an unspecified 'global law' which is supposed to be a novel and popular, albeit vague, normative perspective. ${ }^{29}$

The issue of openness/closeness of a legal system is an enigmatic one. It often appears in works in the field of the theory of law; however, as Zygmunt Ziembiński claims, "it is difficult to grasp the subject of this dispute." ${ }^{30}$ Relying on Ziembiński's opinion, it may be assumed that it concerns the question of whether a legal system at a given developmental stage consists of a specified and stable set of norms, the presence of which is associated with the operation of the legitimate law-making bodies, or whether it is impossible to establish such a rigid set of norms. ${ }^{31}$ Let us take notice of the fact that such an approach to the question clearly accentuates its relation with the formal unity of a legal system, i.e. the criteria determining the belonging of norms to the system.

What may prove useful for a more precise understanding of the issue of the openness/closeness of a legal system is Bertalanffy's division of systems into closed and open ones. ${ }^{32}$ This division was later adopted by

29 See G. Teubner (ed.), Global Law without a State, Dartmouth 1997; G. Teubner, A. Fischer-Lescano, Regime-collisions: the vain search for legal unity in the fragmentation of global law, 'Michigan Journal of International Law' 2004, vol. 25, no 4, at p. $999 \mathrm{ff}$.

30 Z. Ziembiński, Problemy podstawowe prawoznawstwa [Basic problems of jurisprudence], op. cit., p. 230.

31 Ibid.

32 L. von Bertalanffy, Ogólna teoria systemów [General theory od systems], op. cit., pp. 69-70. 
Niklas Luhmann, among others. According to Bertalanffy, a closed system is a system isolated from its environment. Its opposite is an open system, remaining in various relations to its environment. The main feature of the latter is equifinality, meaning that the final state can be reached in different ways and from varying initial conditions. Open systems may have negative entropy, i.e. they may aim towards states of increased orderliness and organisation. The question arises whether law is (or may be) such a system? Does law as a system gravitate towards structure and order? Undoubtedly, such an idealistic assumption underlies every legal order, which finds its expression in codification tendencies. What if facts contradict it? Does such a disorderly legal order become less valuable than law that operates in a straitjacket of a system intuitively understood as an orderly set of elements? These questions seem to be particularly important and relevant in the context of international law.

While discussing the problems of legality and legitimacy, we face three basic questions. 1) Can we, in the case of international law seen as a system, speak of consistency and unity assuming a lack of identity between what is legal and legitimate ('illegal but legitimate')? How should this lack of identity, or even conflict, be resolved? Is what is legal subordinate to what is legitimate or vice versa? Are these, perhaps, equal and autonomous attributes of international law, to which the relation of subordination is not applicable? It is at this point that we need to note that given the positive answer to the question at issue, it is either impossible to consider the two as elements of one whole, or, alternatively, if they are equal elements of one whole, they break its normative unity, assuming their being in opposition to each other. 2) Assuming the autonomy of legality and legitimacy, can we not see legitimacy as a 'safety valve,' supporting the systemicity of international law in the context of its completeness? This pertains to situations in which what is legitimate is referred to in the absence of a clear legal rule, i.e. when there is a danger of the dispute-resolving body deciding it to be non liquet; such situations undermine the systemicity of a legal order, as they threaten its completeness. 3) How do legality and legitimacy influence relations between legal rules in the context of their consistency and hierarchy?

Let us begin the discussion of the relation between legality and legitimacy by explaining these terms. Legality is not particularly difficult to explain. Let us adopt here the following definition: legal is what finds justification in the legal rules in force, i.e. a legal action is an action that has appropriate legal grounds. This is an example of a pleonasm - legal means justified by law being legally legitimate. In this context, the legalistic 
approach is an approach within a legal order that recognises as justified only actions that are not contrary to the binding legal rules enforced by competent bodies.

The meaning of legitimacy is significantly more problematic. In its primary meaning, to legitimise is to justify due to, by implication, something. Following this line of reasoning, 'legal' can be understood as justified due to its conformity with the rules of law. The supporters of the 'illegal but legitimate' approach do not, however, attach major importance to legality understood as such. Conformity with the non-legal factor justifying the legitimacy of the rules of law is here of superior value when compared to conformity with the rules of law. The discrepancies in this respect result from a lack of agreement as to the definition of law and its relation to ethics (ethical values), i.e. various philosophies of law. Hence also the differences in the understanding of legitimacy of international law.

We can talk about two basic meanings of the legitimacy of law: normativist and sociological. ${ }^{33}$ In the normativist sense, law is legitimate if there is a basis (reason) justifying the validity of law and the necessity to observe its rules. In this understanding, the legitimacy of law is thus its justification and explanation, i.e. its 'original grounds. ${ }^{34}$ The normativist legitimacy aims to provide an answer to the question about the grounds of the validity of law and law-making and about the justification of an exercise of power on its basis. In the sociological (descriptive) sense, law is legitimate when its subjects (the addressees of norms) are convinced of its binding force and the necessity to observe it. Such a sociological legitimacy is close to the legalist approach to law in the sense that legalists consider sociological legitimacy, i.e. the social acceptance of law, to be an ideal. The broader and more uniform the conviction is, the stronger the sociological legitimacy of law, and thus the deeper the establishment of legalism among its subjects. It does not overlap with the normativist legitimacy of law in the sense that sociologically legitimate law is not a sufficient condition for its original legitimisation, i.e. legitimacy in the normativist sense, as a wrong

33 Cf. A. Buchanan, R.O. Keohane, The Legitimacy of Global Governance Institutions, [in:] R. Wolfrum, V. Röben (eds.), Legitimacy in International Law, Springer, BerlinHeidelberg-New York 2008, at p. 25; A. Buchanan, The Legitimacy of International Law, [in:] S. Besson, J. Tasioulas (eds.), Philosophy of International Law, Oxford University Press, Oxford 2010,at p. 79. See also J. Raz, The Authority of Law. Essays on Law and Morality, $2^{\text {nd }}$ ed., Oxford University Press, Oxford 2009, pp. 28-33.

34 A. Kozak, Legitymizacja prawa [Legitimisation of law], [in:] A. Bator et al., Wprowadzenie do nauk prawnych. [Introduction to legal sciences], op. cit., at p. 44. 
law may also become socially accepted. The sociological legitimacy of law should be seen as a natural consequence of the original legitimisation of law when the subjects of law highly value the law in force. In this sense, it is secondary to the normativist legitimacy. It may be said that in the normativist sense legitimacy is legitimisation ex ante, whereas legitimacy in the sociological sense is legitimisation ex post. ${ }^{35}$ Thus, it is possible to legitimise both ex ante and ex post within the legal order.

Legitimisation ex ante reduces the question of the legitimacy of law to the problem of justifying the binding force of the whole legal system, i.e. the reason for its validity in a given community. The question of the legitimacy of law is, therefore, primarily a question of the grounds for its validity and obligatory nature. Regardless of the answer to the question about the reason for complying with the law (e.g. the validity of legal orders, the fear of sanctions, the legitimate manner of establishing norms), it is necessary to emphasise the unquestionable order-making competence of the normativistically legitimate law, stemming from the original legitimisation of its existence. ${ }^{36}$

The question concerning the ex ante legitimacy of law is, in fact, a fundamental question of legal philosophy. ${ }^{37}$ The answer to it is the expression of the philosophical views on law par excellence. The views on the legitimacy of law can thus be seen as a demarcation criterion between traditionally opposite trends of jurisprudence, i.e. between thetic (mainly normativistic and positivistic) and axiological justifications of its validity. The problem of legitimacy marks the boundary between these directions in jurisprudence that see the basis of the validity of law in non-legal factors (axiological - the school of natural law, social rules - sociologism or the 'rules' of historical development - historicism) and those who seek to justify the validity of law by referring to actual or hypothetical features of the legislator, especially his will (the thetic justification of law, characteristic

35 D. Bodansky, The concept of legitimacy in international law, [in:] R. Wolfrum, V. Röben (eds.), op. cit., at pp. 314-315.

36 Cf. ibid., pp. 310-311.

37 It is worth quoting the following excerpt from Oppenheim's International Law in this context: "It is not possible to say why international law as a whole is binding upon the international community without entering the realm of non-legal considerations." Oppenheim's International Law, ed. by R. Jennings, A. Watts, vol. I, Longman, LondonNew York 1996, p. 14. See also J.L. Brierly, The Basis of Obligation in International Law, [in:] Idem, The Basis of Obligation in International Law and Other Papers, ed. by H. Lauterpacht, C.H. Waldock, Clarendon Press, Oxford 1958, at pp. 64-67. 
of positivism), or by referring to the systemic nature of law (normativism, analytical jurisprudence).

The problem of the legitimacy of international law is as old as its science. What is more, the 'founding fathers' of the science of international law would begin their examinations by discussing the justifications for the validity of the law of nations, i.e. its 'original legitimisation.' In its beginnings, the science of national law was closely related to philosophy, even to the point of becoming indistinguishable from it. Along with the positivisation of international law and the expansion of legal positivism, the question of legitimacy, as a 'non-scientific' one, began to be pushed to the background, or even ignored. Today, however, the fact that law is not a 'being in itself and for itself,' i.e. it cannot justify its own validity, becomes increasingly more obvious, and we observe growing interest in the problem of the legitimacy of international law, also among the proponents of legal positivism. It is symptomatic that the re-emergence of the issue of the legitimacy of international law, over the last two decades, is associated with a book by Thomas Franck ${ }^{38}$ which is considered, though not quite rightly so, to be a neo-positivist attempt at justifying the legitimacy of international law. The significance of the problem of the legitimacy of, and in, international law is emphasised by the popularity of the phrase 'illegal, but legitimate.' It is rejected by supporters of the thetic legitimacy of law, mainly positivists, while supporters of the axiological legitimisation ex ante tend to accept it. ${ }^{39}$ The crucial component here is the answer to the question whether the mutual exclusiveness of legality and legitimacy, and thus the legitimacy of what is illegal within a legal system, is acceptable. Let us thus consider this question and provide an answer to it.

The issue of the interrelation between what is legal and legitimate stems from one of the oldest, most important, and most discussed problems in the philosophy of law - the conflict between ethical values and legal norms. This issue is extensively covered in the relevant literature and, undoubtedly, retains its key importance for the philosophy of law.

In light of the axiological legitimacy of law, it obtains full original validation only as a result of its compliance with a specific axiological ideal - usually variously, and not always consistently, understood justice

38 T.M. Franck, The Power of Legitimacy Among Nations, Oxford University Press, New York-Oxford 1990.

39 See R. Kwiecień, Teoria i filozofia prawa międzynarodowego. Problemy wybrane [Theory and philosophy of international law. Selected problems], Difin, Warszawa 2011, pp. 111-140. 
and/or equity. The legitimacy of law in this perspective is gradable, which is determined by the degree of the approximation of the applicable rules of law to the established axiological ideal. The law rejecting a specific axiological pattern is not legitimised, according to the supporters of this approach. In extreme cases, it is even denied legal nature. The latter position seems paradoxical, as it claims that something that it is nominally a law, i.e. an unjust law, is not a law. The supporters of the axiological legitimisation of law, however, argue that if an unjust law deviates from the ideal of law and distorts its idea, it may not be considered to be a law. A law that is not legitimised in such an extreme way, is not a law, even if it is applied and observed. In this perspective, legality is not legitimised. Hence, the proponents of the non-positivist legitimacy aim to change legal rules in force. This issue of the relation between legitimacy and legality in the form of the interrelation of justice and legal security, which is of key importance to the legalistic approach, is expressed in a balanced way by the Radbruch's formula. ${ }^{40}$

In fact, it is only in the axiological perspective that the tension between legitimacy and legality remains important, or even inevitable, as it is this very perspective that particularly emphasises the necessary ontic relation between moral and legal norms. The thetic, especially positivist, legitimacy of law is essentially void of this tension. Legal norms that are created in compliance with established procedural requirements and make use of the acceptance of a competent legislative body are legitimised, which fully justifies the obligation to act in conformity with their disposition (legality), regardless of the degree of the axiological saturation of the content of orders, prohibitions, or permissions. Simultaneously, a legal action becomes an action that is legitimised; therefore, the binding legal rules entail the obligation to comply with them. In the perspective of the axiological legitimacy of law, however, the following antinomies are possible: 1) legal but not legitimate; 2) illegal but legitimate. The former opposition contributes to legal safety, whereas the latter insists on the implementation, by means of legal norms, of values external to the legal system, which thus legitimises them. In the philosophy of law, the standpoints that attempt to legitimise law from the outside use the legitimacy understood as such in order to relativise the positivistically-understood legality. These are represented by supporters of the axiological (ethical) legitimacy, those

40 See G. Radbruch, Filozofia prawa [Philosophy of law], transl. E. Nowak, PWN, Warszawa 2009, p. 250. 
referring to the so-called social justice, or the laws of historical processes, campaigning for reforms or even revolutionary changes of existing legal rules.

The presented issues are not foreign to international law. The events of the last two decades in international relations are a spectacular representation of the tension between legitimacy and legality in international law. One notable example is the legal qualification of NATO armed action against Serbia in 1999. In its report, the Independent International Commission concluded that "... the NATO military intervention was illegal but legitimate." ${ }^{41}$ However, this raises the question about the meaning of this statement within international law. The question whether the phrase 'illegal but legitimate' has any cognitive value in international law is a particularly interesting one. The opposition between legality and legitimacy clearly attempts to justify the illegality of actions by employing reasons that are external to law yet outweigh legal prohibitions. There arises, however, the previously mentioned fundamental question of whether an action that has no legal basis in the law in force, i.e. is illegal, may to any extent constitute a legally legitimate action. In other words, are we not dealing here with an internal contradiction? Another issue to consider is the influence of the tension between the axiologically-justified legitimacy and legality on the inner (thetic) legitimacy of international law and, consequently, its effectiveness.

The weight of the above quandaries depends primarily on the scope of meaning that we attribute to law. If law is understood more widely than in its positivistic sense, as is characteristic of the doctrine of natural law, the conflict between legitimacy and legality does not result in a greater problem, as it is unanimously resolved to the advantage of legitimacy. In other words, legality is recognised here in the prism of legitimacy, whereas law itself is seen as incomplete in a certain way. If, however, law is understood in a narrower sense, i.e. as a set of interrelated principles and norms

41 The Independent International Commission on Kosovo, The Kosovo Report. Conflict, International Response, Lessons Learned, Oxford 2000. The broad debate within international law scholarship followed NATO action. See AJIL 1999, vol. 93, no 4, EJIL 1999, vol. 10, no 1, EJIL 2001, vol. 12, no 3, ICLQ 2000, vol. 49, no 4 and T.M. Franck, Interpretation and change in the law of humanitarian intervention, [in:] J.L Holzgrefe, R.O. Keohane (eds.), Humanitarian Intervention. Ethical, Legal, and Political Dilemmas, Cambridge University Press, Cambridge 2003, at p. 204 ff.; P. Valek, Legality versus Legitimacy and the Use of Force, [in:] R.A. Miller, R.M. Bratspies (eds.), Progress in International Law, Martinus Nijhoff Publishers, Leiden-Boston 2008, at p. $615 \mathrm{ff}$. 
established, applied, and enforced by competent entities, this conflict will prove to be of key importance to the legal system, as it threatens one of its foundations, i.e. legal safety. ${ }^{42}$ It can also threaten its systemicity, due to the possibility of gaps in law. The compliance of actions/omissions with legal norms (legality) is not, within such a conflict, the only criterion for the assessment of these actions and the exercise of power within a legal system. Here, an alternative to legality are non-legal patterns, the use of which may lead to the statement 'illegal but legitimate.' Can a judge accept illegal actions on the basis of non-legal considerations? If, as Montesquieu insisted, judges are 'the mouth of law,' then the answer is negative. On the other hand, the Roman legal tradition claims that ius est ars boni et aequi.

In order to be recognised as legitimate by the supporters of the axiologically legitimate law, actions/behaviours need to correspond to a certain ideal of law. Thus, their compliance with the disposition of legal norms becomes a secondary issue. Legitimacy, in other words, is a necessary and sufficient condition of legality. On the other hand, legality as seen from this perspective, is not a sufficient condition of legitimacy; indeed, it is not even a necessary condition of legitimacy, if the difference between legal and legitimate ('illegal but legitimate') is tolerated or even accepted. ${ }^{43}$ Such an approach is especially noticeable in the area of jus ad bellum. In the framework of the axiological legitimacy of international law, a unilateral military action, i.e. an action without legitimacy in the decisions of the UN Security Council, does not preclude the legitimacy of such an action if it serves specific values. The legality of such an action is merely an additional and certainly not the most important - criterion for its assessment and legal qualification. Let us, however, once again ask the question whether condoning illegal activities does not deprive international law of legitimacy. In light of Thomas Franck's concept of legitimacy, the answer to the above question is unanimously positive, since tolerating violations blurs the boundary between what is allowed and what is prohibited. Consequently, it jeopardizes the crucial element of Franck's theory of legitimacy - determinacy. ${ }^{44}$ It seems that this aspect of the internal legitimacy of law should not be dismissed. While examining the legitimacy of norms, institutions, and activities in the field of international law, one cannot ignore the obliga-

42 Cf. D. Bodansky, The Concept of Legitimacy, op. cit., at p. 311.

43 Cf. A. D’Amato, On the Legitimacy of International Institutions, [in:] Wolfrum, Röben (eds.), op. cit., at pp. 83-84, who states: "Legitimate does not mean lawful."

44 T.M. Franck, The Power of Legitimacy, op. cit., pp. 50-56, 84-90. 
tion to primarily analyse the legality of the processes of their creation and application. Ignoring legality is against the foundation of law and leads to the paradoxical conclusion that what is illegal remains justified (legitimate).

Legitimacy should not be considered as an alternative to legality, because it is a meta-legal justification of what has been granted by legal means. The legitimacy of international law simply justifies the establishment of law in the international community. In this sense, illegal actions may not be legitimate. Ignoring legality is destroying the foundation of the legal system, which ultimately leads to the loss of its legitimacy. Therefore, any concept of legitimacy that condones violations of legality ought to be rejected. ${ }^{45}$

Are all legal actions, however, equally legitimate? ${ }^{46}$ It may reasonably be called into question because a varying degree of legality may be attributed to actions/omissions that are in compliance with international law. Their classification into legal and illegal is an oversimplification. Judge Simma in his declaration to the Advisory Opinion of the ICJ of 22 July 2010 on Accordance with International Law of the Unilateral Declaration of Independence in respect of Kosovo, convincingly criticised the binary division of actions/omissions of States into legally permissible and prohibited. There are, as Simma emphasises, varying degrees of legality, as both actions that are required by law and those that are not contrary to the disposition of legal norms (non-prohibited) are considered legal. Furthermore, there are various degrees of what is non-prohibited, from actions/omissions that are tolerated to permissible and desirable ones. ${ }^{47}$ Correspondingly to the above division, we may distinguish various degrees of legitimacy of actions/omissions, accounting for the importance and position of the norm being the model of legality in a given case, within the structure of the system of international law. In essence, legal action/omissions may be allowed varying degrees of legitimacy.

It may be useful to refer here to the example of the United Nations collective security system. The UN Security Council, acting under Chapter

45 Cf. G. Abi-Saab, The Security Council as legislator and as executive in its fight against terrorism and against proliferation of weapons of mass destruction: the question of legitimacy, [in:] Wolfrum, Röben (eds.), op. cit., at p. 116.

${ }^{46}$ Cf. A. Pellet, Legitimacy of legislative and executive actions of international institutions, [in:] Wolfrum, Röben (eds.), op. cit., at p. 67.

47 Accordance with international law of the unilateral declaration of independence in respect of Kosovo (Advisory Opinion), Declaration of Judge Simma, ICJ Reports 2012, at pp. 480-481,paras. 8-9. 
VII of the United Nations Charter ('action with respect to threats to the peace, breaches of the peace and acts of aggression') acts, as practice shows, in various ways. Cases where the Security Council was unable to allow for the use of force under the UN Charter, yet it was used for humanitarian considerations, exemplify the formula 'illegal but legitimate.' Let us discuss such behaviour of the Security Council in light of what is legal and legitimate. The UN Charter leaves the Security Council autonomous with respect to decisions on actions in the event of a threat to the peace, a breach of the peace, or acts of aggression, as well as to assess whether any of the above circumstances has taken place. A lack of a decision by the Security Council and the resulting absence of armed action is, thus, not contrary to law but rather constitutes a legal action, as it adopts the decision of the Security Council in this respect. However, these are actions of a varying degree of legitimacy. From the point of view of the objectives of the UN Charter and the central position of the Security Council within the collective security system, particularly considering it being given by the UN Charter "the primary responsibility for the maintenance of international peace and security" (Article 24 (1) and the obligation to act in accordance with the Purposes and the Principles of the United Nations (Article 24 (2)), the absence of the Security Council's decision in the event of an objectively apparent breach of the peace, would constitute an action only to be tolerated within the UN Charter, and hence an action with a low degree of legitimacy, ${ }^{48}$ whereas the adoption of a decision by the Security Council in this respect, as an action that is desirable within the UN Charter, ought to be attributed a considerably higher degree of legitimacy.

To summarise the discussion on legality and legitimacy, one should recognise a necessary relation between them. Legality is a necessary condition of legitimacy within international law. Unjustified, or even destructive to the legal system, is the acceptance of the position expressed by the 'illegal but legitimate' formula. This position is inherently contradictory because it attempts to present what is devoid of system-internal (thetic) justification as legitimate in the legal system. Thus, it threatens legal security, since it attempts to justify the shaping of the situation of legal subjects by means of arbitrary and inconsistent actions taken on the basis of often conflicting values. It must also be assumed that what is legal is also legitimate.

48 Cf. E. de Wet, The legitimacy of United Nations Security Council decisions in the fight against terrorism and the proliferation of weapons of mass destruction. Some critical remarks, [in:] Wolfrum, Röben (eds.), op. cit., at. p. 123. 
The degree of legitimacy of a given action/omission may, however, differ depending on its approximation to the model (ideal) action present in the provision of the norm constituting the criterion for its assessment and its purpose and position in the normative structure of international law.

\section{The relationship between legality and legitimacy under the systemic features of international law}

Rejecting the thesis that what is illegal may be legitimate in international law has specific consequences for the systemic features of international law. They can be encapsulated as follows:

1) the standpoint that what is illegal may not be legitimate strengthens the normative and axiological unity of international law, as it attributes legal significance only to values that have been internalised in the binding legal norms; therefore, what is legal is simultaneously legitimate.

2) completeness of international law can only be ensured by the binding rules of law, rather than by values external to the legal system, unless the rules themselves provide for such a possibility (e.g. the possibility of resolving a dispute by the International Court of Justice ex aequo et bono under Article 38(2) of its Statute); on the one hand, it may weaken completeness due to possible gaps in law, yet, on the other hand, it strengthens unity and consistency, as discussed below;

3) in the perspective of the thesis that what is illegal may not be legitimate and in light of the rejection of the subordination of legal rules to non-legal values, there remains no conflict between law and values, which, in turn, serves to protect coherence between legal rules; at the same time, it does not solve the problem of the hierarchy of legal norms, particularly with respect to the status and importance of peremptory norms within the system of international law;

4) the non-thetic, especially axiological, legitimacy of international law opens it to external non-legal elements; from this perspective, international law becomes vulnerable to the conflict between legal rules and values, and thus the openness can threaten coherence and unity; the rejection of such legitimacy of international law and opting for the thetic legitimacy is, at the same time, opting for the systemic closeness of the system of international law; this, however, does not constitute an obstacle to the openness of international law to national legal orders, provided that the validative rules of international law allow it. 
Legality is of fundamental significance to the systemicity of international law, its completeness in particular. If what finds justification in the rules of law in force is 'legal,' then we encounter an 'alegal' situation wherever law is silent, i.e. where there is a gap in law. Gaps in law seem particularly dangerous to courts due to the danger of the declaration of non liquet. In such a situation, the completeness of international law could be ensured by means of reference to a non-legal basis of legitimacy, provided that it is in accordance with the rules of law. Such arguments, however, undermine the unity of international law as a system and speak in favour of its openness to non-legal factors. It may, consequently, undermine the systemic autonomy of international law. For this reason, one should be cautious about such openness, as it blurs the source(s) of normativity of international law.

The remedy to gaps in law can be found in its general principles, which are the source of international law whose normative potential has been the least appreciated by law-applying bodies, courts in particular. Insofar as the conservatism of international courts with respect to employing general legal principles as the basis for decisions concerning the application of law may be understood, similar abstention with reference to interpreting directives in order to derive legal rules from valid treaties, customs, and procedural powers of parties is harder to justify.

Let us consider the question whether it is legal to take action in the absence of clear legal rules. This question is crucial to the completeness of international law. The most influential answer in this respect was provided by the Permanent Court of International Justice (PCIJ) in its judgement concerning S.S. Lotus, ${ }^{49}$ which boils down to the thesis that restrictions on the freedom of States' actions cannot be presumed. Such restrictions may only result from clear prohibiting norms. Does the Lotus doctrine support gaps in law or on the contrary? Much depends on whether the freedom of States' actions, which is the subject of this doctrine, stems from international law or the area that is legally neutral. The most famous passage of the Lotus judgement reads:

International law governs relations between independent States. The rules of law binding upon States therefore emanate from their own free will as expressed in conventions or by usages generally accepted as expressing principles of law and established in order to regulate

49 The case of the S.S. "Lotus" PCIJ Publ. 1927, Series A, No. 10. 
the relations between these co-existing independent communities or with a view to the achievement of common aims. ${ }^{50}$

In light of this dictum, international law is, in essence, a law that operates only in the horizontal dimension and governs the mutual relations of independent entities, that is, in fact, interstate law. The voluntary and, at the same time, state-centric approach to the nature of international law was supported by the consistent position of the PCIJ on the establishment of the scope of the jurisdiction of the international court by the will of States. Its view presented the activities of State bodies undertaken for the protection of citizens as the State's power capacity under international law ${ }^{51}$ and expressed the conviction as to the secondary nature of the legal subjectivity of international organisations. The PCIJ emphasised that international organisations, although remaining autonomous in respect of the established competencies, derive their existence and authority to act from the founding treaties concluded by States. Thus, the legal basis for their activity depends on the consent of States. ${ }^{52}$

The essence of the Lotus case decided by the PCIJ was to establish the legal basis for exercising jurisdiction outside the borders of States. On the one hand, the PCIJ adopted that States may not exceed the limits imposed on them by international law with respect to the exercise of jurisdiction. Within these limits, the entitlement to exercise jurisdiction arises from sovereignty. On the other hand, however, the Hague Court considered the freedom of States to act outside their territories to be a "generally accepted international law." This freedom may only be restricted by specific prohibiting norms. Consequently, the PCIJ rejected the necessity for a State to submit a norm permitting to act $^{53}$ in areas where there are no prohibitions resulting from their consent. Therefore, any restrictions on States' freedom to act, which stems from their sovereignty, may not be presumed. ${ }^{54}$

$50 \quad$ Ibid., p. 18.

51 Case concerning the factory in Chorzów (Claim for indemnity) (Merits), PCIJ Publ. 1928, Series A, No. 17, at p. 28; Case concerning the payment of various Serbian loans issued in France, PCIJ Publ. 1929, Series A, Nos. 20/21, at pp. 17-18; The PanevezysSaldutiskis Railway case, PCIJ Publ. 1939, Series A/B, No. 76, at p. 16.

52 See Competence of the International Labour Organisation to regulate, incidentally, the personal work of the employer (advisory opinion), PCIJ Publ. 1926, Series B, No. 13, at p. 20; Jurisdiction of the European Commission of the Danube between Galatz and Braila (advisory opinion), PCIJ Publ. 1927, Series B, No. 14, at pp. 63-64.

53 The case of S.S. "Lotus" supra note 48, pp. 19-20.

54 Ibid., p. 18. 
The Lotus doctrine actually sees States as international legislators, since it presents the consent of States as a key element of international law, which legitimates the legislative process in respect of prohibiting norms existing within it.

In fact, the Lotus doctrine presents international law as a contractual legal order, within which specific legal obligations are superseded by clear legal obligations. This point of view of the PCIJ was particularly clearly presented in the Oscar Chinn case, in which, despite the differing opinions of Judge Schücking and Judge van Eysing, the PCIJ questioned the pre-emptory nature of norms in international law and thus their potentially constitutional role in the law of the international community. ${ }^{55}$ By rejecting the presumption of the consent of the State to be bound by prohibiting norms, the Lotus doctrine fully validates the consent of States as the foundation of the binding force of international law, i.e. the source of its normativity. The obligation to refrain from specific actions must, in light of this doctrine, result from the approval explicitly expressed in international contracts and/or customs or unilateral acts. The absence of explicit consent means a presumption to the contrary, i.e. the presumption of States' freedom to act. However, at the same time, the importance of this freedom of action of States remains ambiguous for international law, as it can be understood either as a gap in the international legal order, i.e. an area that is not regulated by law, or as an institution of international law, i.e. being subjected to the law permitting States' freedom of action. ${ }^{56}$ The former perspective supports the thesis about the incompleteness of international law, whereas the latter consolidates the opposite thesis. In any case, by means of the theory of consent, the Lotus doctrine attempts to legitimise international law as interstate and contractual law, i.e. a law where States remain authoritative legislators. From this perspective, international law turns out to be a complete legal system, because only what States have permitted can become a normative element of this system. Is such an understanding of international law, however, not too narrow? Does it not arbitrarily exclude from international law participants of interna-

55 The Oscar Chinn Case, PCIJ Publ. 1934, Series A/B, No. 63. See R. Kwiecien, The PCIJ and constitutional dimension of international law: from expectations to reality, [in:] M. Fitzmaurice, Ch. Tams (eds.), Legacies of the Permanent Court of International Justice, Martinus Nijhoff, Leiden 2013, at pp. 380-383.

56 Cf. A. Carty, The Decay of International Law?, op. cit., p. 10; A. Peters, Does Kosovo lie in the Lotus-land of freedom?, 'Leiden Journal of International Law' 2011, vol. 24, at p. 101. 
tional relations other than States, or does it not exclude from the catalogue of sources of law all that is not directly legitimised by the permission of States? Is, thus, the theory of permission, supported by the doctrine of Lotus, enough to legitimise the whole of international law, and not just this part of it that consists of norms prohibiting specific acts from being performed by States?

The widely-criticised Lotus doctrine should not be considered a threat to the systemicity of international law. In its light, the freedom of States' actions should not be construed as a legally indifferent area but rather as an area of the activities of States that is shaped by the permitting norms of international law. Thus, it supports the consistency and completeness of international law. The real threat to these systemic features are the currently prevalent trends in jurisprudence that marginalise the formalism of the sources of international law and thus relativise the legal grounds of actions of international community members on the basis of the so-called transnational law, global governance, and, particularly, global administrative law. ${ }^{57}$

\section{Conclusions}

International law is not, nor was it ever, a closed legal system. In the era of global governance and global administrative law, this is particularly evident. Nonetheless, the departure from the formalism of the sources of law, which is especially the case in the norm-setting practice of non-governmental actors, poses a threat to the consistency of the law of the international community and to its public nature. At the same time, it affects the relationship between legality and legitimacy in international law. This is related to the phenomenon of blurring the formalism of international law sources, which can lead to the marginalisation of the identifying criteria of such sources in the international community. ${ }^{58}$ It seems that the role of States as the 'systemic guardians' of the formal identification of international rights and obligations is difficult to replace, also in the

57 See R. Kwiecień, On some contemporary challenges to statehood..., op. cit., pp. 298-310.

58 See extensively J. d'Aspremont, Formalism and the Sources of International Law. A Theory of the Ascertainment of Legal Rules, OUP, Oxford 2011. 
context of the effects of the activities of non-State actors. ${ }^{59}$ In this sense, the position of States contributes to the strengthening of the systemicity of international law.

Despite the noticeable changes in the international community, taking place across the ideological, institutional, subjective, and normative dimensions, the claim about the validative autonomy of international law which is not equivalent to its closed nature - still appears reasonable. It is, at most, only a relative closeness. Its guards, and thus the guardians of the validative autonomy of international law, are States. This leads to the following two assertions: 1) international law remains, in a manner controlled by States, open to influences from the 'outside,' which leads to the widening of its subjective and objective borders, perhaps at the expense of the clarity of the core of its normativity; 2) actions and behaviour of States remain the guarantee of the publicness of law within the international community. In this sense, States remain the guardians of the systemicity and the normative autonomy of international law. If we refer this conclusion to the classic dichotomy of monism and dualism, we will be forced to opt for the dualism, in the sense that the legislative facts within international law find their validation due to the validation rules of international law that are strictly linked to the legal position of States. Thus, the effectiveness of acts of national law and acts resulting from the norm-setting activity of non-State actors in the international legal order is due to their acceptance or tolerance by States. New doctrinal approaches that attempt to present the law of the international community as a 'global law,' combining within the framework of global governance the mechanisms of national law, the intergovernmental factor, and the role of non-governmental international actors, are not able to convincingly justify the normative identity of the so-called 'global law' without States sanctioning their activities, as the actions of States play the role of the validative 'safety valve' within the international community. In other words, the normativity of the publicness of law within it is difficult, if not impossible, to justify without States. This allows, on the one hand, to preserve the normative (validative) autonomy of international law and, on the other hand, to uphold the adaptive function in relation to new social, cultural, and political phenomena. This adaptive function protects international law from falling into desuetudo and justifies its being recognised as a 'living system.' 


\section{Bibliography}

G. Abi-Saab, The Security Council as legislator and as executive in its fight against terrorism and against proliferation of weapons of mass destruction: the question of legitimacy, [in:] R. Wolfrum, V. Röben (eds.), Legitimacy in International Law, Springer, Berlin-Heidelberg-New York 2008.

J. d'Aspremont, Formalism and the Sources of International Law. A Theory of the Ascertainment of Legal Rules, OUP, Oxford 2011.

J. d'Aspremont (ed.), Participants in the International Legal System. Multiple Perspectives on Non-State Actors in International Law, Routledge, LondonNew York 2011.

J. d'Aspremont, The systemic integration of international law by domestic courts: domestic judges as architects of the consistency of the international legal order, available at http://ssrn.com/abstract=1401019

A. Bator et al., Wprowadzenie do nauk prawnych. Leksykon tematyczny [Introduction to legal science: thematic lexicon], LexisNexis, Warszawa 2006.

E. Benvenisti, The conception of international law as a legal system, 'German Yearbook of International Law' 2007, vol. 50.

L. von Bertalanffy, Ogólna teoria systemów. Podstawy, rozwój, zastosowania, transl. E. Woydyłło-Woźniak, PWN, Warszawa 1984.

D. Bodansky, The concept of legitimacy in international law, [in:] R. Wolfrum, V. Röben (eds.), Legitimacy in International Law, Springer, Berlin-HeidelbergNew York 2008.

J.L. Brierly, The Basis of Obligation in International Law, [in:] Idem, The Basis of Obligation in International Law and Other Papers, ed. by H. Lauterpacht, C.H. Waldock, Clarendon Press, Oxford 1958.

A. Buchanan, R.O. Keohane, The Legitimacy of Global Governance Institutions, [in:] R. Wolfrum, V. Röben (eds.), Legitimacy in International Law, Springer, Berlin-Heidelberg-New York 2008.

A. Buchanan, The Legitimacy of International Law, [in:] S. Besson, J. Tasioulas (eds.), Philosophy of International Law, Oxford University Press, Oxford 2010.

A. Carty, The Decay of International Law? A Reappraisal of the Limits of Legal Imagination in International Affairs, Manchester University Press, Manchester 1986.

J. Combacau, Le droit international: bric-à-brac ou système?, 'Archives de Philosophie du Droit' 1986, vol. 31.

J. Combacau, S. Sur, Droit international public, 4e ed., Montchrestien, Paris 2001.

J. Crawford, International law as an open system, [in:] idem, International Law as an Open System, Cameron May, London 2002.

J. Crawford, The Creation of States in International Law, $2^{\text {nd }}$ ed., OUP, Oxford 2006.

J. Crawford, Chance, Order, Change: The Course of International Law, Hague Academy of International Law 2014. 
A. D’Amato, On the Legitimacy of International Institutions, [in:] R. Wolfrum, V. Röben (eds.), Legitimacy in International Law, Springer, Berlin-HeidelbergNew York 2008.

P.F. Diehl, Ch. Ku, The Dynamics of International Law, CUP, Cambridge 2010.

L. Ehrlich, Prawo międzynarodowe, 4 ed., PWN, Warszawa 1958.

J. Finnis, Revolutions and continuity of law, in: Idem, Philosophy of Law. Collected Essays: Volume IV, OUP, Oxford 2011.

T.M. Franck, The Power of Legitimacy Among Nations, Oxford University Press, New York-Oxford 1990.

T.M. Franck, Interpretation and change in the law of humanitarian intervention, [in:] J.L Holzgrefe, R.O. Keohane (eds.), Humanitarian Intervention. Ethical, Legal, and Political Dilemmas, Cambridge University Press, Cambridge 2003.

J.L. Hargrove, International law as law, law as a system of rule-governed conduct, 'Villanova Law Review' 2011, vol. 56.

H.L.A. Hart, The Concept of Law, $3^{\text {rd }}$ ed., OUP, Oxford 2012.

R. Higgins, Problems and Process: International Law and How We Use It, Clarendon Press, Oxford 1994.

Independent International Commission on Kosovo, The Kosovo Report. Conflict, International Response, Lessons Learned, Oxford 2000.

I. Kant, The Metaphysics of Morals, transl. and ed. M. Gregor, CUP, Cambridge 2000.

N. Krisch, Beyond Constitutionalism. The Pluralist Structure of International Society, OUP, Oxford 2011.

M. Koskenniemi, Study on the function and scope of the lex specialis rule and the question of self-contained regimes, ILC(LVI)/SG/FIL/CRD.1 and Add 1,

M. Koskenniemi, The fate of public international law: between technique and politics, 'Modern Law Review' 2007, vol. 70.

A. Kozłowski, Interpretacja systemowa prawa międzynarodowego, [in:] J. Kolasa, A. Kozłowski (eds.), Rozwój prawa międzynarodowego - jedność czy fragmentacja?, UW, Wrocław 2007.

A. Kozłowski, Interpretacja traktatu międzynarodowego w świetle jego kontekstu, Wydawnictwo Sejmowe, Warszawa 2002.

J.L. Kunz, The systematic problem of the science of international law, [in:] Idem, The Changing Law of Nations. Essays on International Law, Ohio State University Press 1968.

R. Kwiecien, On some contemporary challenges to statehood in the international legal order: international law between 'Lotus' and 'global administrative law, 'Archiv des Völkerrechts' 2013, vol. 51.

R. Kwiecień, Teoria i filozofia prawa międzynarodowego. Problemy wybrane, Difin, Warszawa 2011.

R. Kwiecien, The PCIJ and constitutional dimension of international law: from expectations to reality, [in:] M. Fitzmaurice, Ch. Tams (eds.), Legacies of the Permanent Court of International Justice, Martinus Nijhoff, Leiden 2013.

N. MacCormick, Institutions of Law: An Essay in Legal Theory, OUP, Oxford 2007. 
C. McLachlan, The principle of systemic integration and article 31(3)(c) of the Vienna Convention, 'ICLQ' 2005, vol. 54.

K. Opałek, Problemy metodologiczne nauki prawa, Warszawa 1963.

Oppenheim's International Law, ed. by R. Jennings, A. Watts, vol. I, Longman, London-New York 1996.

The Oxford Dictionary, $2^{\text {nd }}$ ed., Clarendon Press, Oxford 1990.

A.L. Paulus, International legal system as a constitution, [in:] J.L Dunoff, J.P. Trachtman (eds.), Ruling the World? Constitutionalism, International Law, and Global Governance, CUP, Cambridge 2009.

A. Pellet, Legitimacy of legislative and executive actions of international institutions, [in:] R. Wolfrum, V. Röben (eds.), Legitimacy in International Law, Springer, Berlin-Heidelberg-New York 2008.

A. Peters, Does Kosovo lie in the Lotus-land of freedom?, 'Leiden Journal of International Law' 2011, vol. 24.

G. Radbruch, Filozofia prawa, transl. E. Nowak, PWN, Warszawa 2009.

J. Raz, The Authority of Law. Essays on Law and Morality, $2^{\text {nd }}$ ed., Oxford University Press, Oxford 2009.

J. Raz, The identity of legal systems, [in:] idem., The Authority of Law, $2^{\text {nd }}$ ed. OUP, Oxford 2009.

R. Sarkowicz, J. Stelmach, Teoria prawa, UJ, Kraków 1996.

M. Shaw, International Law, $6^{\text {th }}$ ed., CUP, Cambridge 2008.

J.-M. Sorel, V. Boré Eveno, Art. 31, 1969 Vienna Convention, [in:] O. Corten, P. Klein (eds.), The Vienna Conventions on the Law of Treaties, OUP, Oxford 2011.

G. Teubner (ed.), Global Law without a State, Dartmouth 1997.

G. Teubner, A. Fischer-Lescano, Regime-collisions: the vain search for legal unity in the fragmentation of global law, 'Michigan Journal of International Law' 2004, vol. 25.

P. Valek, Legality versus Legitimacy and the Use of Force, [in:] R.A. Miller, R.M. Bratspies (eds.), Progress in International Law, Martinus Nijhoff Publishers, Leiden-Boston 2008.

I. Venzke, How Interpretation Makes International Law. On Semantic Change and Normative Twists, OUP, Oxford 2012.

E. de Wet, The legitimacy of United Nations Security Council decisions in the fight against terrorism and the proliferation of weapons of mass destruction. Some critical remarks, [in:] R. Wolfrum, V. Röben (eds.), Legitimacy in International Law, Springer, Berlin-Heidelberg-New York 2008.

G.O. Zabalza, The Principle of Systemic Integration: Towards a Coherent International Legal Order, LIT Verlag, Zürich-Berlin 2012.

Z. Ziembiński, Problemy podstawowe prawoznawstwa, PWN, Warszawa 1980.

Z. Ziembiński, S. Wronkowska, A. Redelbach, Zarys teorii państwa i prawa, PWN, Warszawa 1994. 